\title{
Determination of factors affecting competitiveness through technical and economic analyses of dairy cattle enterprises in Balıkesir province
}

\author{
Burak MAT ${ }^{1, a, ~}$, , Yavuz CEVGER $^{2, b}$ \\ ${ }^{1}$ Selçuk University, Faculty of Veterinary Medicine, Department of Animal Health Economics and Management, Konya, Turkey; \\ ${ }^{2}$ Ankara University, Faculty of Veterinary Medicine, Department of Animal Health Economics and Management, Ankara, Turkey \\ ${ }^{\mathrm{a} O R C I D: 0000-0002-0455-8736 \text {; }{ }^{\text {} O R C I D: ~ 0000-0002-2806-2532 ~}}$
}

Corresponding author: burakmat@ selcuk.edu.tr

Received date: 08.12.2020 - Accepted date: 20.05.2021
\end{abstract}

\begin{abstract}
In this study, technical and economic analysis of dairy cattle enterprises in Balıkesir province were carried out. The factors which affect the competitiveness of enterprises and are important in terms of the continuity of production were determined. The stratified sampling method was used to determine the sample, and the study material was two-year (2017-2018) data obtained from 147 enterprises. In addition to the economic analysis of the data obtained, factors affecting unit profit in enterprises were estimated using the multiple linear regression model. The cost elements in total enterprises in Balıkesir province in 2017-2018 include feed expenses (47.90\%-47.29\%), livestock depreciation (16.64\%-16.13\%), labor expenses (13.84\%-14.30\%), veterinary health expenses (4.03\%-4.50\%), fuel transportation expenses (3.43\%-4.15\%), building equipment depreciation (3.37\%-3.64\%), and other expense items. A distinct difference was observed between scales in terms of profit and loss states of the enterprises in the study, with an increase in the profitability level from small toward large scale enterprise. The small-scale enterprises, in particular, are at a loss. The most important determinant of competitiveness in the study is the region's development level, where the enterprises are established in the borders of Balıkesir province. Additionally, among the technical parameters, the calving interval and the reduction of the disease rate have a positive effect on the competitiveness of the enterprises. Therefore, improving the financial structure of the enterprises and boosting the rate of technology utilization while simultaneously increasing enterprise scales will contribute positively to competitiveness.
\end{abstract}

Keywords: Balıkesir province, competitiveness, dairy cattle, economic analysis.

\section{Balıkesir ilinde bulunan süt sığırcılığı işletmelerinin teknik ve ekonomik analizi ile rekabet gücünü etkileyen faktörlerin belirlenmesi}

Özet: $\mathrm{Bu}$ araştırma, Balıkesir ili süt sığırcılık işletmelerinin teknik ve ekonomik analizini gerçekleştirmek ve işletmelerin üretimde devamlılıkları açısından önemli olan rekabet güçlerini etkileyen faktörlerin işletme düzeyinde belirlenmesi amacıyla yapılmıştır. Örneklem tespitinde, tabakalı örnekleme yöntemi kullanılmış olup, çalışma materyalini 147 adet işletmeden elde edilen iki yıllık (2017-2018) veriler oluşturmaktadır. Elde edilen verilerin değerlendirilmesinde yapılan ekonomik analizlerin yanı sıra işletmelerde birim kâra etkili faktörler çoklu doğrusal regresyon modeli ile tahmin edilmiştir. Balıkesir ili genelinde 2017-2018 yıllarında toplam işletmelerde masraf unsurları sırasıyla yem gideri (\%47,90-\%47,29), canlı demirbaş amortisman (\%16,64-\%16,13), işçilik giderleri $(\% 13,84-\% 14,30)$, veteriner sağlık gideri (\%4,03-\%4,50), akaryakıt nakliye gideri (\%3,43-\%4,25), bina ekipman amortismanı $(\% 3,37-\% 3,64)$, diğer gider kalemleri yer almıştır. Çalışmadaki işletmelerin kâr zarar durumlarında ise ölçekler arasında belirgin bir farklılık oluşmakta, kârlılık seviyesi küçük ölçekten büyük ölçeğe doğru artış göstermektedir. Özellikle küçük ölçekli işletmelerin zarar ettiği tespit edilmiştir. Çalışmada rekabetin en önemli belirleyicisi işletmeler bakımından Balıkesir ili sınırları içerisinde kurulu olduğu bölgenin gelişmişlik düzeyidir. Buna ek olarak teknik parametrelerden buzağılama aralığı ve hastalık oranın azaltılmasının işletmelerin rekabet gücüne olumlu etki ettiği anlaşılmıştır. Sonuç olarak işletme ölçeklerinin büyütülmesi ile eş zamanlı olarak işletmelerin finansal yapısının iyileştirilebilmesi ve teknoloji kullanım oranının artırılabilmesi rekabet gücüne olumlu yönde katkı sağlayacaktır.

Anahtar sözcükler: Balıkesir ili, ekonomik analiz, rekabet gücü, süt sığırcılığı. 


\section{Introduction}

Livestock activities fulfill critical economic functions as a source of livelihood and employment of Turkey's rural population. Although animal production activities in Turkey are carried out across the country, it could not provide the expected and desired added value increase to the general population. Besides, positive developments have not been continuous (11). The success not achieved in terms of increasing added value has a negative effect on the competitiveness of exports of animal products $(35,41)$.

The "Revealed Comparative Advantage" Indices have been calculated as comparative advantage and competitiveness for Turkey and European Union countries with respect to the product group under the title of live animals. According to this index, Turkey's comparative advantage and competitiveness are not at par with the level of FAO's livestock category classification in European Union member country markets (38).

Balıkesir province is a developed region in terms of livestock production (21), and a significant part of the province's economy is based on livestock farming (42); thus, making the economic evaluation of dairy cattle breeding strategic. In Turkey, dairy cattle breeding is one of the most dynamic branches of production among the sub-sectors of the farming industry (2). Considering the dairy cattle breeding sector in Turkey, particularly the dairy cattle enterprises in Balıkesir province, as well as the potential changes in domestic and foreign markets, in addition to the performance of milk producers, the importance of competitiveness among enterprises is also increasing. It is important to examine and reveal the level of competitiveness among dairy cattle enterprises (28). As an outcome of the identification and analysis of the factors affecting competitiveness in dairy cattle enterprises, it is important to adopt the measures necessary to boost the competitiveness and the performance of the enterprises in terms of setting relevant policies.

In summary, dairy cattle enterprises that cannot make a profit arguably do not have competitiveness (20). In other words, under perfectly competitive conditions, a product introduced to the market and having a higher cost than the market price reveals that dairy enterprises do not have competitiveness (19). Therefore, profitability is the basic measure of competitiveness in enterprises (9) and has been considered as a measure of competitiveness in line with the objective of this study.

This study aimed to perform technical and economic analyses of dairy cattle enterprises in Balıkesir province and determine the factors affecting competitiveness at the enterprise level, which is critical in terms of the production continuity of the enterprises.

\section{Materials and Methods}

Primary data from Balıkesir Province Cattle Breeders Association-member enterprises located in Balıkesir province was obtained using study materials and the data collection form.

In determining the sample, the average and variance weights of each layer were considered using the stratified sampling method, and a single sample volume of the layers was determined. Accordingly, the study's sample size was 135 Balıkesir Province Cattle enterprises Association member enterprises from the 6066 enterprises registered in the Ministry of Agriculture and Forestry system. Twelve more enterprises were added to the study to create a reserve; finally, 147 enterprises were included in the study $(7,18)$. Among the enterprises with dairy cattle in Balıkesir province, the enterprises containing 110 milked cows were classified as small, those with 1150 milked cows as medium-scale, and with 51 and above milked cows were considered as a large-scale enterprise.

For this study, a data collection form was used for face-to-face interviews with representatives from dairy cattle enterprises. In the data collection form, questions were designed to evaluate the physical and technical structures of the enterprises and their economic analysis. The data were transferred to the computer, and expense elements comprising the cost determined for milk production, income elements, and the cost of producing one liter of milk $(25,32)$, enterprises' input, output values, and capital structures were calculated $(26,32)$.

The Republic of Turkey's central bank values has been calculated based on the recent United States Dollar (USD) rate in 2017 and 2018. As of the last day of December, 1 unit of USD was announced as 3.77 TRY 5.26 TRY in 2017 and 2018 (12).

Calving interval is measured as the time between two live calves from a cow. The disease rate was calculated as the number of sick animals / total animals (4).

Statistical analysis: The Microsoft Excel (Microsoft Office Professional Plus 2010) and SPPS 25 (23) statistical package programs were used to process the data obtained in 2017-2018 from the dairy cattle enterprises included in the study. As variables, the mean \pm standard deviation and the median (Maximum-Minimum) percentage, and frequency values were used. Variables were evaluated after checking the normality and homogeneity pre-conditions of the variances (ShapiroWilk and Levene Test). During the data analysis, when the comparison of three or more groups was not provided using One-Way Analysis of Variance and the multiple comparison test Tukey HSD, Kruskal Wallis, and the Bonferroni-Dunn multiple comparison tests was used (3, $6,27)$. The values accepted for the significance level of the tests are $\mathrm{P}<0.05$ and $\mathrm{P}<0.01$. 
Multivariate regression analysis was performed for a large number of determined and measured variables. No elimination method (backward, forward) was used. Analyses were evaluated in accordance with the partial regression parameters obtained in the developed model. $\beta$ The coefficients show how and in which direction a change of 1 unit in the relevant variable will cause a change in $\mathrm{Y}$ when other variables are kept fixed (39).

The regression equation divided into developed and undeveloped regions was applied for profit and loss, and for this, all 2017-2018 data were used.

The function to be applied for study data is,

$\mathrm{Y}=\mathrm{f}\left(\mathrm{X}_{1} \mathrm{~b}_{1}, \mathrm{X}_{2} \mathrm{~b}_{2}, \mathrm{X}_{3} \mathrm{~b}_{3}, \mathrm{X}_{4} \mathrm{~b}_{4}, \ldots \mathrm{X}_{\mathrm{n}} \mathrm{b}_{\mathrm{n}}\right)$,

and is formulated as follows:

$$
\begin{aligned}
& \mathbf{Y}=\mathbf{b}_{0}+\mathbf{b}_{1} \mathbf{X}_{1}+\mathbf{b}_{2} \mathbf{X}_{2}+\mathbf{b}_{3} \mathbf{X}_{3}+\mathbf{b}_{4} \mathbf{X}_{4+} \\
& \text {.................... } b_{n} X_{n}+\varepsilon \\
& Y_{i}=b_{0}+b_{1} X_{1}+b_{2} X_{2}+b_{3} X_{3}+b_{4} X_{4+} b_{5} X_{5}+ \\
& \mathbf{b}_{6} \mathbf{X}_{6}+\mathbf{b}_{7} \mathbf{X}_{7}
\end{aligned}
$$

In the model developed within the scope of the study, the dependent variable was taken as profit/loss (TRY) per L of milk. (Y)

\section{$\varepsilon=$ Error Term}

$\mathrm{X}_{1}=$ Milk yield per cow/year (tons);

$\mathrm{X}_{2}=$ Feed (coarse + concentrate) cost (TRY) per L of milk;

$\mathrm{X}_{3}=$ Active Capital (TRY) per Lt of milk;

$\mathrm{X}_{4}=$ Amount of loan (TRY) used per liter of milk;

$\mathrm{X}_{5}=$ Number of cows per enterprise;

$\mathrm{X}_{6}=$ Calving interval (days);

$\mathrm{X}_{7}=$ Rearing disease rate (Number of sick animals/Total number of animals);
$\mathrm{X}_{8}=$ Developed and underdeveloped regions (Categorical variable encoded as a dummy)

Note: $\mathrm{X}_{8}$ is the developed and underdeveloped region variable that was evaluated considering the table of socioeconomic development level according to the districts of Balıkesir province published by the Ministry of Agriculture and Forestry (40).

\section{Results}

In the economic analysis tables prepared for each enterprise in this study, the expense elements comprising the cost and their ratio within the total expense were evaluated in detail according to the scale of enterprises. The expense elements comprising the average cost of the dairy cattle enterprises in Balıkesir province for 2017 and 2018 are presented in Table 1 and Table 2, respectively.

According to Table 1, in 2017, the largest share in total operating expenses in Balıkesir province was that of feed expenditure at $47.90 \%$, followed by an average livestock depreciation at $16.64 \%$, while the average labor expenses were $13.84 \%$, and other expenditure items had a $21.62 \%$ share.

Analysis on the basis of scales revealed that while feed cost and the rates of building and equipment depreciation were higher for large-scale enterprises, labor cost and fuel transportation expense rates were higher for small-scale enterprises.

Further analysis in terms of scales revealed that the difference between scales statistically significant in 2017 in terms of veterinary health, labor, electricity, water,

\begin{tabular}{|c|c|c|c|c|c|}
\hline 2017 & $\underset{(\%)}{0-10 \text { Small }} \mathbf{n}=58$ & $\underset{(\%)}{11-50} \underset{\text { Medium }}{n}=74$ & $\begin{array}{c}51+\underset{(\%)}{\text { Large }} \mathrm{n} \\
=15\end{array}$ & $\begin{array}{c}\text { Total } n=147 \\
(\%)\end{array}$ & $\mathbf{p}$ \\
\hline Feed & $47.90 \pm 14.26$ & $48.44 \pm 8.67$ & $51.46 \pm 6.59$ & $47.90 \pm 11.05$ & 0.56 \\
\hline Veterinary health & $4.32 \pm 1.66$ & $3.73 \pm 1.7$ & $4.58 \pm 1.68$ & $4.03 \pm 1.70$ & $<0.05$ \\
\hline Labor & $16.81 \pm 5.31 \mathrm{a}$ & $12.8 \pm 3.83 \mathrm{a}$ & $7.76 \pm 2.79 b$ & $13.84 \pm 5.15$ & $<0.001$ \\
\hline Electricity water & $1.47 \pm 0.89 \mathrm{a}$ & $1.09 \pm 1.11 \mathrm{a}$ & $2.23 \pm 0.9 \mathrm{~b}$ & $1.34 \pm 1.06$ & $<0.001$ \\
\hline Fuel transportation & $3.81 \pm 3.09$ & $3.35 \pm 1.64$ & $2.42 \pm 1.3$ & $3.43 \pm 2.30$ & 0.12 \\
\hline Insurance & $0.05 \pm 0.2 \mathrm{a}$ & $0.16 \pm 0.45 \mathrm{a}$ & $1.71 \pm 1.84 b$ & $0.26 \pm 0.81$ & $<0.001$ \\
\hline Loan interest & $0.13 \pm 0.58$ & $0.54 \pm 1.48$ & $0.35 \pm 0.85$ & $0.36 \pm 1.16$ & 0.14 \\
\hline Land rent & $1.46 \pm 2.17$ & $1.87 \pm 2.67$ & $1.07 \pm 1.98$ & $1.63 \pm 2.42$ & 0.42 \\
\hline Inventory value decrease & $2.30 \pm 5.44$ & $2.69 \pm 7.98$ & $0.59 \pm 2.06$ & $2.33 \pm 6.79$ & 0.56 \\
\hline Milk food & $1.90 \pm 1.04$ & $2.11 \pm 0.78$ & $2.22 \pm 1.11$ & $2.04 \pm 0.92$ & 0.33 \\
\hline $\begin{array}{l}\text { Building equipment } \\
\text { depreciation }\end{array}$ & $3.47 \pm 2.63 \mathrm{a}$ & $2.62 \pm 1.5 \mathrm{a}$ & $7.07 \pm 4.71 b$ & $3.37 \pm 2.72$ & $<0.001$ \\
\hline Maintenance repair & $0.70 \pm 0.5$ & $0.97 \pm 1.59$ & $0.8 \pm 0.79$ & $0.85 \pm 1.21$ & 0.45 \\
\hline Livestock depreciation & $16.00 \pm 5.45$ & $17.43 \pm 4.36$ & $15.47 \pm 3.37$ & $16.64 \pm 4.77$ & 0.14 \\
\hline General administration & $2.23 \pm 0.3$ & $2.20 \pm 0.27$ & $2.27 \pm 0.35$ & $2.22 \pm 0.23$ & 0.67 \\
\hline
\end{tabular}
insurance, and building equipment depreciation costs $(\mathrm{P}<0.05)$.

Table 1. Cost elements constituting the 2017 cost of enterprises according to scales $\left(X \pm \mathrm{S}_{\mathrm{x}}\right)$.

\footnotetext{
$* \mathrm{a} ; \mathrm{b}$; ; There is a statistically significant difference for variables with different letters in the same row.
} 
According to Table 2, of the total operating expenses in Balıesir province in 2018, feed expenses had the largest share, with an average of $47.29 \%$, followed by livestock depreciation with an average of $16.13 \%$, labor expenses at $14.30 \%$ on an average, and other expenditure items had a $22.28 \%$ share. Further analysis revealed that while feed cost, building, and equipment depreciation rates were higher for large-scale enterprises, labor cost and fuel transportation expense rates were higher for smallscale enterprises.

The difference between scales was found to be statistically significant in 2018 in terms of labor, electricity, water, insurance, building equipment depreciation, and living stock depreciation costs $(\mathrm{P}<0.05)$.

The average cost of milk/L and the amount of profit and loss per enterprise across the dairy cattle enterprises were estimated for the period of 2017-2018 and are presented in Table 3.

Analysis of Table 3 shows a decrease in the average cost of milk/L as the enterprise-scale increases. In smallscale enterprises, the cost of milk, which was 1.63 TRY (0.43 USD) in 2017, increased to 1.70 TRY (0.32 USD) in 2018. In the medium-sized enterprises, the cost of milk, which was 1.36 (0.36 USD) TRY in 2017, increased to 1.39 TRY (0.26 USD) in 2018, and in the large-scale enterprises, the cost of milk increased from 1.13 TRY (0.29 USD) in 2017 to 1.09 TRY (0.20 USD) in 2018.

Investigation of the profit and loss statement of the enterprises shows distinct differences between the enterprises, with the profitability level increasing from small scale toward large scale.

Table 2. Cost elements constituting the 2018 cost of enterprises according to scales $\left(X \pm \mathrm{S}_{\mathrm{x}}\right)$.

\begin{tabular}{|c|c|c|c|c|c|}
\hline 2018 & $\begin{array}{c}0-10 \text { Small } n \\
(\%)\end{array}$ & $\begin{array}{c}\text { 11-50 Medium } \\
(\%)\end{array}$ & $\begin{array}{c}51+\text { Large } n \\
(\%)\end{array}$ & $\begin{array}{c}\text { Total } n=147 \\
(\%)\end{array}$ & $\mathbf{p}$ \\
\hline Feed & $45.56 \pm 14.25$ & $48.4 \pm 7.88$ & $49.71 \pm 5.68$ & $47.29 \pm 11.03$ & 0.23 \\
\hline Veterinary health & $4.53 \pm 2.17$ & $4.34 \pm 1.84$ & $5.18 \pm 2.21$ & $4.50 \pm 2.02$ & 0.35 \\
\hline Labor & $17.45 \pm 6.48 \mathrm{a}$ & $12.77 \pm 3.26 b$ & $7.79 \pm 2.75 c$ & $14.30 \pm 5.78$ & $<0.001$ \\
\hline Electricity water & $1.52 \pm 1.02 \mathrm{a}$ & $1.24 \pm 1.11 \mathrm{a}$ & $2.57 \pm 1.2 \mathrm{~b}$ & $1.49 \pm 1.14$ & $<0.001$ \\
\hline Fuel transportation & $4.55 \pm 3.37$ & $4.04 \pm 2.01$ & $2.94 \pm 1.39$ & $4.15 \pm 2.67$ & 0.1 \\
\hline Insurance & $0.17 \pm 0.59 \mathrm{a}$ & $0.40 \pm 0.88 \mathrm{a}$ & $1.27 \pm 1.46 \mathrm{~b}$ & $0.39 \pm 0.89$ & $<0.001$ \\
\hline Loan interest & $0.30 \pm 1.54$ & $0.47 \pm 1.25$ & $0.65 \pm 1.19$ & $0.41 \pm 1.37$ & 0.61 \\
\hline Land rent & $1.76 \pm 2.78$ & $1.57 \pm 1.93$ & $1.01 \pm 2.45$ & $1.59 \pm 2.37$ & 0.54 \\
\hline Inventory value decrease & $0.51 \pm 2.29$ & $0.47 \pm 2.17$ & $0.03 \pm 0.12$ & $0.44 \pm 2.10$ & 0.73 \\
\hline Milk food & $2.02 \pm 1.21$ & $2.17 \pm 1.3$ & $2.15 \pm 0.91$ & $2.10 \pm 1.22$ & 0.78 \\
\hline $\begin{array}{l}\text { Building equipment } \\
\text { depreciation }\end{array}$ & $3.48 \pm 2.74 \mathrm{a}$ & $3.08 \pm 2.01 \mathrm{a}$ & $6.87 \pm 4.98 b$ & $3.64 \pm 2.95$ & $<0.001$ \\
\hline Maintenance repair & $0.72 \pm 0.54$ & $0.94 \pm 1.04$ & $0.72 \pm 0.57$ & $0.82 \pm 0.72$ & 0.24 \\
\hline Livestock depreciation & $14.78 \pm 5.24 \mathrm{a}$ & $17.38 \pm 4.69 b$ & $16.26 \pm 2.55 \mathrm{a}$ & $16.13 \pm 4.91$ & $<0.01$ \\
\hline General administration & $2.65 \pm 0.71$ & $2.71 \pm 0.41$ & $2.86 \pm 0.44$ & $2.69 \pm 0.55$ & 0.42 \\
\hline
\end{tabular}

* a; b; c; There is a statistically significant difference for variables with different letters in the same.

Table 3. Financial findings of the milk production according to the enterprise scale $\left(X \pm S_{x}\right)$.

\begin{tabular}{|c|c|c|c|c|c|}
\hline \multirow{2}{*}{\multicolumn{2}{|c|}{ Scale }} & \multicolumn{2}{|c|}{$\begin{array}{l}\text { One Lt Milk Cost } \\
\text { (TRY) }\end{array}$} & \multicolumn{2}{|c|}{$\begin{array}{l}\text { Profit Loss } \\
\text { (TRY) }\end{array}$} \\
\hline & & 2017 & 2018 & 2017 & 2018 \\
\hline \multirow{2}{*}{ Small } & $\mathrm{n}$ & 58 & 58 & 58 & 58 \\
\hline & $\mathrm{X} \pm \mathrm{S}_{\mathrm{x}}$ & $1.63 \pm 0.62$ & $1.70 \pm 0.58$ & $-4671.53 \pm 24758.32$ & $-4915.96 \pm 21791.7$ \\
\hline \multirow{2}{*}{ Medium } & $\mathrm{N}$ & 74 & 74 & 74 & 74 \\
\hline & $\mathrm{X} \pm \mathrm{S}_{\mathrm{x}}$ & $1.36 \pm 0.5$ & $1.39 \pm 0.5$ & $20552.66 \pm 69203.88$ & $21111.07 \pm 77537.96$ \\
\hline \multirow{2}{*}{ Large } & $\mathrm{n}$ & 15 & 15 & 15 & 15 \\
\hline & $\mathrm{X} \pm \mathrm{S}_{\mathrm{x}}$ & $1.13 \pm 0.64$ & $1.09 \pm 0.41$ & $816264.38 \pm 1190627.66$ & $804057.58 \pm 1118220.17$ \\
\hline \multirow{2}{*}{ Total } & $\mathrm{n}$ & 147 & 147 & 147 & 147 \\
\hline & $\mathrm{X} \pm \mathrm{S}_{\mathrm{x}}$ & $1.44 \pm 0.58$ & $1.49 \pm 0.56$ & $86382.32 \pm 430690.23$ & $89672.07 \pm 425923.66$ \\
\hline
\end{tabular}

Footnote: At the end of December 2017 and 2018, 1 unit of USD was 3.77 TRY -5.26TRY. 
Table 4. The results of the regression analysis of the variables affecting profit per liter of milk (2017-2018).

\begin{tabular}{|c|c|c|c|c|c|c|}
\hline \multirow[b]{2}{*}{ Parameters } & \multicolumn{6}{|c|}{ (2017-2018) } \\
\hline & & $\mathbf{N}$ & $\boldsymbol{\beta}$ & $\mathbf{t}$ & Sig. & VIF \\
\hline Fixed & & & -6.249 & -1.917 & .056 & \\
\hline Milk yield per cow, tons & $\mathrm{X}_{1}$ & 294 & .097 & .658 & .511 & 1.420 \\
\hline Feed cost per 1 liter of milk & $\mathrm{X}_{2}$ & 294 & -.025 & -.063 & .950 & 1.207 \\
\hline Active capital per 1 liter of milk & $\mathrm{X}_{3}$ & 294 & .083 & 6.164 & .000 & 1.425 \\
\hline Loan amount per 1 liter of milk & $\mathrm{X}_{4}$ & 294 & .368 & 1.949 & .050 & 1.303 \\
\hline Number of cows milked & $\mathrm{X}_{5}$ & 294 & .013 & 3.712 & .000 & 1.224 \\
\hline Calving interval, day & $\mathrm{X}_{6}$ & 294 & -.021 & 3.091 & .002 & 1.167 \\
\hline Disease rate $\%$ & $\mathrm{X}_{7}$ & 294 & -.163 & -3.219 & .001 & 1.044 \\
\hline Region & $\mathrm{X}_{8}$ & 294 & 1.182 & 2.832 & .005 & 1.062 \\
\hline
\end{tabular}

Footnote: $\mathrm{R}^{2}: 0.330, \mathrm{~F}: 17.563, \mathrm{P}<0.05$

$\mathbf{Y}=6.249+0.097 \mathbf{X}_{1}-0.025 \mathbf{X}_{2}+0.083 \mathbf{X}_{3}+0.368 \mathbf{X}_{4}+0.013 \mathbf{X}_{5}-0.021 \mathbf{X}_{6}-0.163 \mathbf{X}_{7}+1.18 \mathbf{X}_{\mathbf{8}}$

The regression analysis of the variables affecting profitability per liter of milk from the 147 enterprises in Balıkesir province in 2017-2018 is presented in Table 4.

According to Table 4, the adjusted determination coefficient, which expresses the ratio of the independent variables to explain the dependent variable, was estimated to be $\mathrm{R}^{2}: 0.330$, and the $\mathrm{F}$ test, which states the significance of the model, was F: 17.563. Further, the amount of profit/loss per liter of milk, which is a dependent variable in the regression method, is explained by $33.0 \%$ of variables, and that the model is valid $(\mathrm{P}<0.05)$.

\section{Discussion and Conclusion}

In studies on the economic analysis of dairy cattle enterprises conducted in the previous years, feed expenditures had the largest share among the cost elements comprising expenses, followed by labor, depreciation, veterinary health expenses, maintenance and repair costs, and other expenses $(5,13,15,22,24,31)$.

There has been a change in the order of the expense of cost elements in dairy cattle enterprises in Balıkesir. This change resulted from the great increase in cattle values and energy expenses.

Despite the dairy cattle enterprises in Balıkesir province failing to cultivate their coarse fodder crop at low costs with their own means, the share of feed expenses in the grand total of costs was lower than the rates found by other researchers $(13,22,24,31,36)$, as the share of livestock depreciation and energy costs were high.

When labor costs are evaluated in terms of scale size, the ratio of labor expenses among expenses clearly decreases in percentage as the enterprise-scale grows. Compared to results obtained in other studies, labor expense rates were similar for small-scale enterprises and lower for medium and large-scale enterprises (13, 22, 24, $31,36)$. The reason for this difference is the development of technology and increased use of machinery and technology in production in recent years; thus, highly boosting the rate of machinery use in medium and largescale enterprises. Accordingly, an increased rate of machinery use significantly increases the rates of equipment depreciation, especially in large-scale enterprises compared to the other scale enterprises. It, therefore, causes a proportional decrease in labor costs. Additionally, the widespread recruitment of foreign nationals, especially in medium and large-scale enterprises, is another factor that reduces labor costs $(1,14)$.

The ratio of veterinarian - medicine costs among total expenses seems to differ among certain studies $(5,13$, $15,22,24,31)$. The primary reasons for this are the increase in the rate of dairy culture and crossbreeds in the Balıkesir province in recent years, and inadequate suitable care and hygiene conditions for these breeds in enterprises milk yield. Considering enterprise owners' easy access to information through technology, and the importance of the economic value of veterinary health services in cattle enterprises in recent years, the veterinary health expenses item may increase.

Evaluation of the insurance expense item has shown that the proportional share of animal life insurance expenses in small and medium-scale enterprises is very low and is proportionally higher in large-scale enterprises. The most important feature of animal life insurance is that large-scale enterprises understand its function as a guarantee for the continuity of producers' income from the enterprise (29).

The most important challenge is controlling the costs without negatively affecting production, reproduction, animal welfare, and continuity in personnel employment. Costs can be successfully controlled by considering these factors and regular reviews (37).

In addition to the fluctuations in livestock enterprise production costs and milk prices, problems in production and marketing directly affect the producer (5). 
According to the National Milk Council data for enterprises having ten or more cattle, the cost of one liter of milk was calculated to be 1.18 TRY - 1.37 TRY at the end of 2017-2018 (43). This is similar to the results of a study conducted in Konya province in 2017 in terms of scales to the cost of one liter of milk (33). However, the cost of one liter of milk in 2017-2018 announced by the national milk council was lower than the values calculated in this study. In the evaluation made according to enterprise scales, the large-scale enterprises clearly differed significantly from other scales in terms of their understanding of the enterprise and professional management and reduction in the production cost with effective cost control. It has been observed that the required cost control and follow-up on the basis of small and medium-scale enterprises are not up to the desired standard. Thus, production cost drives dairy cattle enterprises to face the complex dilemma of aiming to maximize economic efficiency and minimize costs (30).

For all the dairy cattle enterprises included in this study, the average profit was calculated as $86382.32 \mathrm{TRY}$ (22913.08 USD) in 2017, and 89672.07 TRY (17047.92 USD) in 2018, indicating that the resource use of smallscale enterprises in Ballkesir province is not rational. Small and medium-scale enterprises, in particular, do not consider important cost items such as depreciation and labor in their calculations. This situation shows that enterprise owners are critically mistaken while calculating costs, assuming that their costs are low and that their enterprises are profitable.

The relationship between the enterprise's profit per liter of milk and various variables was analyzed using the regression model and the data of the enterprises included in the study.

According to the regression equation, active capital per liter of milk, the number of cows milked, calving interval, rearing disease rate, and the region variable significantly affect the profit-loss dependent variable per liter of milk (Table 4) $(\mathrm{P}<0.05)$.

The regression model data obtained from dairy cattle enterprises included in the relevant regression model revealed that the active capital is not being used efficiently. Increased and efficient use of active capital investment in animal husbandry enterprises is directly proportional to the growth of technology investment (8, 10). The importance of adopting new technologies to enterprises and increasing the rate of technical innovation has been understood, especially in small and mediumsized enterprises, for Balıkesir dairy cattle enterprises to switch from loss to profit and ensure the sustainability of the enterprises.

The small scale of enterprises and lack of expertise in animal production prevent output growth and the continuity of increasing returns (16). Evaluation of the statistical significance of the independent variable, the number of cows milked, in terms of the scale's efficiency, based on regression model data, reveals that the productivity of the scale may increase in Balikesir province. In the regression model established in enterprises with high milk yield due to profitability, a significant relationship between the rate of disease and breeding was observed. The primary reason for this is predicted to be the higher rate of certain breeding diseases in these enterprises with high milk yield. Though the calving interval presents less effect statistically, shortening this interval will reduce economic loss and thus enable further competitiveness of enterprises. In a study, it was found that shortening the calving interval increased the gross margins between $13 \%$ and $35 \%$ (34).

Greater profitability per liter of milk in developed regions compared to underdeveloped regions is found to be statistically significant. In this case, it is understood that the location of the dairy cattle enterprises and their interactions with the environment significantly affect profitability per liter of milk. Based on the location of the enterprise, supporting economic enviroment and main sectors in the environment can be advantageous in terms of cost-effectiveness, priority, and rapid raw material input supply $(17,20)$.

From this study, it is clear that the socio-economic data used in the analysis of dairy cattle enterprises are mostly quantitative but do not provide a qualitative result. In case dairy cattle enterprises incur a high cost for one liter of milk and low profitability, it is often recommended to reduce costs and increase milk production. However, the origin of these problems is not specified. If regression models are used to determine the factors affecting enterprises' competitiveness, both quantitative and qualitative results can be obtained.

Feed costs can be reduced by increasing feed conversion rates by supporting more active use of pasture areas and increasing the use of feed mixer machines over a certain scale. Furthermore, different additional practices can be implemented to encourage producers, who possess a certain area per cattle and have knowledge and experience to expand their enterprise scale.

It should be known that developing medium-scale enterprises have different needs than large-scale enterprises to grow and benefit from the scale economy. Insufficient funding and the need for financial management expertise can be cited as appropriate examples.

According to the model developed, it is obvious that the dairy cattle enterprises in developed regions have a greater advantage in competitiveness as they earn higher profits. Reducing the disease rate by implementing effective herd health management will positively contribute to the competitiveness of enterprises. 
Additionally, the measures to be taken to improve enterprises' financial structure and increase the rate of technology use with simultaneous upsizing of enterprise scales will increase competitiveness.

\section{Acknowledgments}

This research article was summarized from the first author's PhD thesis. A part of this study was presented in the $4^{\text {th }}$ International Mardin Artuklu Scientific Research Congress, 2020.

\section{Financial Support}

This research received no grant from any funding agency/sector.

\section{Ethical Statement}

This study does not present any ethical concerns.

\section{Conflict of Interest}

The authors declared that there is no conflict of interest.

\section{References}

1. Akın AC, Sipahi C, Çevrimli MB, et al (2020): Büyükbaș hayvancıllk işletmelerinde yöneticilerin işgücü memnuniyet düzeyleri. MAE Vet Fak Derg, 5, 48-57.

2. Akın AC, Tekindal MA, Arıkan MS, et al (2020): Modelling of the milk supplied to the industry in Turkey through Box-Jenkins and winters exponential methods. Vet Hek Der Derg, 91, 49-60.

3. Anscombe FJ (1948): The validity of comparative experiments. J R Stat Soc Ser A Stat Soc (General), 111, 181-211.

4. Aral Y, Arıkan MS (2019): Süt çiftçiliği iyi uygulama rehberi, süt sığırcılığı işletmelerinde kârlılık ve ekonomik sürü yönetimi'ne ilişkin genel prensip ve uygulamalar. Pınar Enstitüsü. ISBN 146, 978-605-83006-3-7.

5. Aşkan E, Dağdemir V (2016): TRA1 Düzey 2 Bölgesinde destek ve teşvik alan süt slğırcıllı̆̆ işletmelerinde süt üretim maliyeti ve karlllık durumu. Tarım Eko Araş Derg, 2, 1-12.

6. Bonferroni CE (1936): Teoria statistica delle classi e calcolo delle probabilità. Pubblicazioni del R Istituto Superiore di Scienze Economiche e Commerciali di Firenze, 8, 3-62.

7. Botev Z, Ridder A (2017): Variance reduction. Wiley statsRef: Statistics ref online: 1-6.

8. Brito MM, Ferenc IB, Sandra MSB, et al. (2015): Horizontal arrangements and competitiveness of smallscale dairy farmers in Paraná, Brazil. Int Food Agribusiness Manag Rev, 18, 155-172.

9. Buckley PJ, Pass CL, Prescott K (1988): Measures of international competitiveness: A critical survey. J Mark Manag, 4,175-200.

10. Cabrera WE, Solis D, Corral J (2010): Determinants of technical efficiency among dairy farms in Wisconsin. $\mathbf{J}$ Dairy Sci, 9, 387-393.
11. Can MF (2018): Türkiye hayvancılık politikalarının AB ile etkileşimi ve olası sonuçları. Atatürk Üniv Vet Bil Derg, 13, 242-250.

12. CBRT (2021): Indicative Central Bank of the Republic of Turkey USD currency rates. https://www.tcmb.gov.tr/ kurlar/kurlar/tr.html (Accessed March 19, 2021).

13. Cicek H, Tandogan M (2008): Economic analysis of dairy cattle activity in Afyonkarahisar province. Mediterr Agric Sci, 21, 179-184.

14. Cevrimli MB, Gunlu A, Mat B, et al (2020): A study on the validity and reliability of the level of employee satisfaction at livestock farming enterprises in Turkey. Acta Vet Eurasia, 46, 45-54.

15. Demir P, Yılmaz A, Sarı̈zkan S (2014): Kars ili süt sığırcılık işletmelerinin sosyo-ekonomik yapısı ve üretim maliyetleri. Van Vet J, 25, 1-6.

16. Domingez RRP, Jordan CMA, Castenada FEM (2014): Contribution of Family Labour to The Profitability and Competitiveness of Small-Scale Dairy Production Systems in Central Mexico. Trop Anim Health Prod, 46, 235-240.

17. Erekoğlu H (2008): İmalat sanayi rekabet gücü araştırmas1: Kayseri örneği. Palme Yayıncılık.

18. Esfahani S, Dougherty M, Edward R (2014): Effect of separate sampling on classification accuracy. Bioinformatics, 30, 242-250.

19. Furat A, Dirlik S (2008): Türkiye Avrupa Birliği Sektörel Rekabet Analizleri. Editör: Selahattin Bekmez, Nobel Yayınları, Ankara. ISBN: 978-605-395-161-2.

20. Gökmenoğlu SM, Akal M, Altunışık R (2012): Ulusal rekabet gücünü belirleyen faktörler üzerine değerlendirmeler. Competition Journal/Rekabet Dergisi, 13.

21. GMKA (2018): Balıkesir Tarım ve Hayvancılık Yatırım Rehberi. Available at https://www.gmka.gov.tr/ dokumanlar/yayinlar/Balikesir-Tarim-ve HayvancilikYatirim-Rehberi.pdf. (Accessed May 08, 2020).

22. Günlü A, Halit İ, Tekerli M (2001): Afyon ili süt sığırcllık işletmelerinin genel özellikleri ile karlılık ve verimlilik analizler. Lalahan Hay Araşt Enst Derg, 41, 1-12.

23. IBM (2017): IBM SPSS Statistics for Windows, Version 25.0. Armonk, NY: IBM Corp.

24. İçöz Y (2004): Bursa ili süt sığırcılık işletmelerinin kârlılık ve verimlilik analizi. Doktora Tezi. Ankara Üniversitesi Sağlık Bilimleri Enstitüsü, Ankara.

25. Kıral T, Kasnakoğlu H, Tatlıdil FF, et al (1999): Tarımsal ürünler için maliyet hesaplama metodolojisi ve veri tabanı rehberi. Tarımsal Ekonomi Araştırma Enstitü Proje Raporu, 13.

26. Köse N (2009): Türkiye muhasebe standartları kapsamında tekdüzen muhasebe sisteminin tarım işletmelerinde uygulanmasının değerlendirilmesi. Doktora Tezi. Ankara Üniversitesi Fen Bilimleri Enstitüsü, Ankara.

27. Kruskal WH, Wallis WA (1952): Use of ranks in onecriterion variance analysis. J Am Stat Assoc, 47, 614-617.

28. Luehrman TA, Kester WC (1989): Are We Feeling More Competitive Yet? The Exchange Rate Gambit. MIT Sloan Management Review 30, no. 2 (winter 1989): 19-28.

29. Mat B, Çevrimli MB, Tekindal MA, et al (2020): Büyükbaş ve küçükbaş hayvancılık işletmelerinin hayvan hayat sigortası yaptırmalarına etki eden faktörlerin belirlenmesi. Eurasian J Vet Sci, 36, 287-297. 
30. Mouritus MCM, Hurne RBM, Dijkhuizen AA, et al (1999): Economic optimization of dairy heifer management decisions. Agricultural System, 61, 17-31.

31. Nizam S, Armağan G (2006): Aydın ilinde pazara yönelik süt sı̆̆ırcılı̆̆ işletmelerinin verimliliklerinin belirlenmesi. ADÜ Ziraat Derg, 3, 53-60.

32. Oğuz C, Bayramoğlu Z (2015): Tarım Ekonomisi. Atlas Akademi.

33. Örs A, Oğuz C (2019): Comparison of economic analysis of dairy farms supported and non-supported by IPARD program: a case study of Konya Province, Turkey. Custos E Agronegocio on Line, 15, 192-212.

34. Razzaque MA, Bedair M, Abbas, S, et al (2009): Economic impact of calf mortality on dairy farms in Kuwait. Pak Vet J, 29, 97-101.

35. Sakarya E, Çevrimli MB, Arıkan MS (2020): Kasaplık siğırlarda karkas sinıflandırma ve derecelendirmenin önemi ve gelişimi: Bir güncelleme. Eurasian J Vet Sci, 36, $146-158$.

36. Santos CC, DE Almeida Júnior GA, Lopes MA (2018): Dairy activity in family farming in Minas Gerais, Brazil: production costs and cost-effectiveness analysis. Semina: Ciências Agrárias, 39, 1255-1266.
37. Shoemaker D, Eastridge M, Breece D, et al (2008): 15 Measures of dairy farm competitiveness. Ohio State University. Dairy Herd Management. Exten Bul. 864.

38. Şahinli MA (2012): Rekabet gücü: Türkiye ve Avrupa Birliği üyesi ülkelerde canlı hayvancılık sektörünün durumu. Van Vet J, 22, 91-98.

39. Tarı R (1999): Ekonometri. Alfa Basım Yayım Dağıtım.

40. Tarım ve Orman Bakanlı̆̆ı (2019): İlçelerin sosyo ekonomik gelişmişlik düzeyleri. Available at https://balikesir.tarimorman.gov.tr/Lists/Duyuru/Attachme nts/128/Ek-2\%20Sosyo\%20Ekonomik\%20Geli\%C5\%9 Fmi\%C5\%9Flik\%20D\%C3\%BCzeyi.pdf. (Accessed May 20, 2020).

41. Turan Z, Şanver D, Öztürk K (2017): Türkiye'de hayvancılık sektöründen süt inekçiliğinin önemi ve yurt içi hasılaya katkısı ve de dış ülkelerle karşılaştırılması. Ömer Halisdemir Üniv İktisadi ve İdari Bil Fak Derg, 10, 60-74.

42. TÜİK (2019): Livestock statistics. Turkish Statistical Institute. Available at http://www.tuik.gov.tr/Start.do. (Accessed September 13, 2020).

43. Ulusal Süt Konseyi (2019): 1 Liter of raw milk cost by regions. Available at https://ulusalsutkonseyi.org.tr/ bolgelere-gore-1-litre-cig-sut-maliyeti-1637/. (Accessed August 20, 2020). 